\title{
ANALISIS LINTAS PERTUMBUHAN DAN PRODUKSI TERHADAP PROTEIN KACANG TUNGGAK (Vigna unguiculata L) GENERASI M2
}

\author{
Yukarie Ayu Wulandari ${ }^{1}$, Sobir ${ }^{2 *}$, Syarifah Iis Aisyah ${ }^{2}$ \\ ${ }^{1}$ Program Studi Aroteknologi Fakultas Pertanian Universitas Muhammadiyah \\ Jakarta Jl. Kh.Achmad Dahlan Cireundeu Ciputat Timur Tangerang Selatan 15419, \\ Indonesia \\ ${ }^{2}$ Departemen Agronomi dan Hortikultura Fakultas Pertanian Institut Pertanian \\ Bogor Jl. Meranti Babakan Dramaga Bogor 16680, Indonesia \\ *E-mail: rsobir@yahoo.com
}

\begin{abstract}
ABSTRAK
Kacang tunggak ( $V$. unguiculata $\mathrm{L}$ ) dapat dikembangkan sebagai sumber protein nabati karena mengandung protein relatif tinggi dan lisin yang tinggi. Kandungan protein pada biji merupakan akumulasi dari komponen karakter yang berperan dalam pembentukan protein, yang hubungannya dapat diduga menggunakan koefisien korelasi dan analisis lintas. Penelitian dilaksanakan di kebun percobaan PKHTt Pasir Kuda IPB. Analisis protein dilaksanakan di Laboratorium Pengujian Departemen Agronomi dan Hortikultura Fakultas Pertanian IPB. Penelitian dilakukan menggunakan 30 genotipe uji mutan putatif generasi M2 hasil induksi mutasi iradiasi sinar gamma dan genotipe KM4 sebagai pembanding yang diulang tiga kali. Kandungan protein biji dianalisis menggunakan metode Kjeldahl kemudian dilakukan analisis ragam, koefisien korelasi dan lintas. Hasil penelitian menunjukkan bahwa mutan putatif generasi M2 menunjukkan keragaman untuk karakter kandungan protein pada biji kacang tunggak. Tinggi tanaman dan jumlah cabang dapat dijadikan karakter seleksi untuk menduga kandungan protein biji kacang tunggak.
\end{abstract}

Kata kunci: iradiasi sinar gamma, karakter seleksi, keragaman, Kjeldahl, mutatn putatif

\section{ABSTRACT}

Cowpea (V. unguiculata $L$ ) can be developed as a source of vegetable protein because it contains relatively high protein and high lysine. The protein content in seeds is an accumulation of character components that play a role in protein formation, whose relationship can be predicted using cross correlation and analysis coefficients. The study was carried out in the experimental garden of Pasir Kuda PKHT of IPB. Protein analysis is carried out in the Testing Laboratory of the Department of Agronomy and Horticulture, Faculty of Agriculture, IPB. The study was conducted using 30 putative mutant test genotypes of M2 generation result from the mutation of gamma ray irradiation and KM4 genotype as a comparison which was repeated three times. The protein content of the seeds was analyzed using the Kjeldahl method and then analyzed the variance, correlation coefficient and path. The results showed that M2 generation putative mutants showed diversity for the character of protein content in cowpea seeds. Plant height and number of branches can be used as selection characters to estimate the protein content of cowpea seeds.

Keywords: diversity, gamma ray irradiation, Kjeldahl, putative mutant, selection character 


\section{PENDAHULUAN}

Kacang tunggak ( $V$. unguiculata $\mathrm{L}$ ) dapat dikembangkan sebagai sumber protein nabati sekaligus sebagai pangan fungsional. Kandungann protein kacang tunggak relatif tinggi, yaitu sebesar 22.53 $\%$ (BKPPP. 2014) dan mengandung lisin yang tinggi, sehingga dapat menyempurnakan kualitas protein bijibijian (Somaatmadja, 1990). Sebagai bahan pangan, kacang tunggak dapat dikonsumsi dalam bentuk daun muda, polong muda dan biji muda sebagai sayuran serta biji tua. Kandungan protein pada daun mudanya sebesar 33\% (Okonya dan Maass, 2014), sehingga dapat dijadikan sumber protein nabati alternatif dalam diversifikasi pangan.

Protein merupakan salah satu unsur gizi penting dalam bahan pangan (Triyono, 2010). Kandungan protein pada biji merupakan hasil akumulasi dari komponen karakter agronomi yang berperan dalam pembentukan protein. Keeratan hubungan antara karakter satu dengan karakter yang lain dapat diduga dengan menghitung nilai koefisien korelasi antara kedua karakter. Analisis lintas merupakan analisis lanjutan setelah mencari nilai korelasi. Wirnas et al. (2005) menyatakan bahwa analisis lintas merupakan bentuk analisis struktural yang membahas hubungan kausal antara variabel-variabel dalam sistem tertutup. Dari analisis koefisien lintas ini dapat diketahui pengaruh langsung dan pengaruh tidak langsung antara karakter bebas dengan karakter respon.

Penelitian dilaksanakan untuk mempelajari hubungan antar karakter komponen hasil dengan kandungan protein biji berdasarkan analisis sidik lintas. Informasi yang dihasilkan sangat diharapkan dapat dimanfaatkan lebih lanjut sebagai kriteria seleksi dalam merakit varietas unggul baru kacang tunggak yang berprotein tinggi.

\section{METODE}

Penelitian dilaksanakan di Kebun Percobaan PKHT Pasir Kuda Institut Pertanian Bogor pada bulan Februari sampai Mei 2018. Penelitian menggunakan Rancangan Perbesaran (Augmented design) menggunakan 30 genotipe mutan putatif hasil panen generasi M2 sebagai genotipe uji yaitu T6511, T6533, T6550, T6561, T6571, T6574, T6577, T6591, T6594, T7025, T7027, T7038，T7040，T7058, T7062, T7069,T7520, T7521, T7525, T7543, T7546, T7551, T8028, T8064, T8067, T8514, T8516, T8523, T8527, T8529 dan genotipe KM4 ssbagai pembanding yang diulang tiga kali. Pengamatan dilakukan terhadap karakter kuantitaif meliputi tinggi tanaman, jumlah cabang, panjang tangkai,panjang daun, umur berbunga, umur panen, periode panen dan jumlah biji per polong.

Analisis kandungan protein biji dilaksanakan di Laboratorium Pengujian Departemen Agronomi dan Hortikultura Fakultas Pertanian IPB pada bulan Juni Juli 2018dengan menggunakan metode Kjeldahl menurut AOAC (2001). Sampel ditimbang $1 \mathrm{~g}$, kemudian dihaluskan dan dimasukkan ke dalam labu Kjeldahl, kemudian ditambahkan $7 \mathrm{~g} \mathrm{~K}_{2} \mathrm{SO}_{4}, 0.8 \mathrm{~g}$ $\mathrm{CuSO}_{4}$ dan $12 \mathrm{~mL} \mathrm{H}_{2} \mathrm{SO}_{4}$ pekat ke dalam labu dan dipanaskan dalam almari asap selama 60 menit. Dinginkan selama 1020 menit kemudian ditambahkan aquades hingga volume total $80 \mathrm{~mL}$. Tambahkan $\mathrm{NaOH} \quad 40 \quad \%$ sebanyak $50 \mathrm{~mL}$ dan dilakukan distilasi. Distilat ditampung dalam erlenmeyer yang berisi $30 \mathrm{~mL}$ larutan $\mathrm{H}_{3} \mathrm{BO}_{3} \quad 1 \%$ yang telah diberi indikator campuran. Distilasi dilakukan hingga distilat yang dihasilkan sebanyak $150 \mathrm{~mL}$ kemudian dititrasi dengan larutan $\mathrm{HCl} 0.1 \mathrm{M}$ sampai warna ungu muda terbentuk. Dibuat juga larutan blanko dengan mengganti sampel dengan aquades, lakukan distilasi, dan titrasi seperti pada sampel. 
Perhitungan \% N

$\% N=\frac{m L \mathrm{HCl} \text { sample }-m L \mathrm{HCl} \text { blanko } \times \mathrm{M} \mathrm{HCl} \times 14.01}{g \text { sample } \times 10}$

Perhitungan \% protein

$\%$ Protein kasar $=\% N \times$ faktor konversi $(6.25)$

Hasil analisis kandungan protein biji kemudian dilakukan analisis ragam dan uji lanjut LSD pada taraf 5\% menggunakan software SAS. Analisis lintas karakter tinggi tanaman, jumlah cabang, panjang tangkai,panjang daun, umur berbunga, umur panen, periode panen dan jumlah biji per polong terhadap kandungan protein biji kacang tunggak mengunakan software $\mathrm{R}$ statistic. Analisis sidik lintas, menjelaskan keeratan hubungan antar sifat dengan cara menguraikan koefisien korelasi menjadi pengaruh langsung dan pengaruh tidak langsung. Analisis sidik lintas tidak hanya memberikan informasi tentang keeratan hubungan antar sifat, tetapi juga menjelaskan mekanisme hubungan kausal antar sifat melalui lintasan-lintasan terpisah yang dibangun dalam diagram lintas (Wirnas et al., 2005). Korelasi antar karakter agronomi dapat dihitung dengan statistik parameterik dengan analisis korelasi linier sederhana menurut Singh dan Caudhary (1979) sebagai berikut:

$r=\frac{n \Sigma X Y-(\Sigma X)(\Sigma Y)}{\sqrt{\left(n \Sigma(x)^{2}-(\Sigma X)^{2}\right)\left(n \Sigma(Y)^{2}-(\Sigma Y)^{2}\right)}}$

dimana, r: $\mathrm{n}$ korelasi antara karakter bebas terhadap hasil, $\mathrm{n}$ : banyaknya perlakuan, $\mathrm{x}_{1}$ : karakter bebas, $\mathrm{y}_{1}$ : karakter hasil.

Analisis sidik lintas selalu diikuti dengan diagram lintasan agar memperjelas uraian yang dikemukakan. Wirnas et al., (2005) menyatakan mengenai rumus sidik lintas dengan koefisien lintas (Ci) dapat dihitung dengan persamaan sebagai berikut:

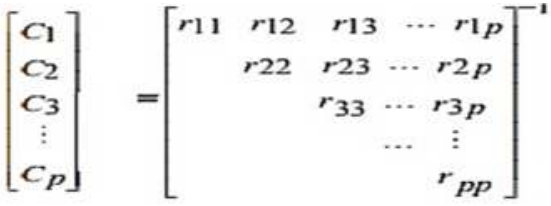

$\left[\begin{array}{c}r_{1} y \\ r_{2} y \\ r_{3 y} \\ \vdots \\ r_{p y}\end{array}\right]$

$\underline{C}=R_{x}^{-1} R_{y}$

$\left[\begin{array}{c}c_{1} \\ c_{2} \\ c_{3} \\ \vdots \\ c_{p}\end{array}\right]=\left[\begin{array}{ccccc}r_{11} & r 12 & r_{13} & \cdots & r_{1 p} \\ & r_{22} & r_{23} & \cdots & r_{2 p} \\ & & r_{33} & \cdots & r_{3 p} \\ & & & \cdots & \vdots \\ & & & & r_{p p}\end{array}\right]^{-1}$

$\left[\begin{array}{c}r_{1} y \\ r_{2 y} \\ r_{3 y} \\ \vdots \\ r_{p y}\end{array}\right]$

$\underline{C}=R_{x}^{-1} R_{y}$

$\left[\begin{array}{c}c_{1} \\ c_{2} \\ c_{3} \\ \vdots \\ c_{p}\end{array}\right]=\left[\begin{array}{ccccc}r_{11} & r_{12} & r_{13} & \cdots & r_{1} p \\ & r_{22} & r_{23} & \cdots & r_{2 p} \\ & & r_{33} & \cdots & r_{3 p} \\ & & & \cdots & \vdots \\ & & & & r_{p p}\end{array}\right]^{-1}$

$\left[\begin{array}{c}r_{1 y} \\ r_{2 y} \\ r_{3 y} \\ \vdots \\ r_{p y}\end{array}\right]$

$\underline{C}=R_{x}^{-1} R_{y}$

\section{HASIL DAN PEMBAHASAN}

Hasil analisis ragam menunjukkan bahwa genotipe mutan M2 yang berpengaruh sangat nyata terhadap kandungan protein biji kacang tunggak. Tabel 1 menunjukkan bahwa terdapat 15 genotipe dengan kandungan protein biji lebih tinggi dan berbeda nyata dengan genotipe KM4 yaitu genotipe T8067, T7525, T8516, T6511, T8064, T8529, T6550, T7027, T7069, T8523, T7543 T6571, T6591, T6533 dan T7551. Kandungan protein biji paling tinggi dihasilkan pada genotipe T8067 yaitu $25.18 \%$, dan kandungan protein biji paling rendah dihasilkan pada genotipe 
T6577 dan T6594 yaitu $22.44 \%$ dan berbeda nyata dengan genotipe KM4.

Kandungan protein pada biji kacang tunggak dipengaruhi oleh komponen karakter agronomi baik pada karakter vegetatif maupun generatif tanaman. Untuk mengetahui karakter yang berpengaruh terhadap kandungan protein biji kacang tunggak, maka perlu dilakukan analisis korelasi dan lintas.

Tabel 1. Keragaan kandungan protein biji genotipe mutan kacang tunggak generasi M2

\begin{tabular}{cccc}
\hline Genotipe & Protein $(\%)$ & Genotipe & Protein $(\%)$ \\
\hline T8067 & $25.18 \mathrm{a}$ & T7058 & $23.81 \mathrm{~b}$ \\
T7525 & $25.01 \mathrm{a}$ & T8514 & $23.81 \mathrm{~b}$ \\
T8516 & $24.90 \mathrm{a}$ & T6574 & $23.75 \mathrm{~b}$ \\
T6511 & $24.78 \mathrm{a}$ & T7025 & $23.64 \mathrm{~b}$ \\
T8064 & $24.72 \mathrm{a}$ & T7038 & $23.53 \mathrm{~b}$ \\
T8529 & $24.67 \mathrm{a}$ & T7520 & $23.35 \mathrm{~b}$ \\
T6550 & $24.50 \mathrm{a}$ & T8028 & $23.13 \mathrm{~b}$ \\
T7027 & $24.44 \mathrm{a}$ & T7040 & $23.07 \mathrm{~b}$ \\
T7069 & $24.44 \mathrm{a}$ & T7521 & $23.01 \mathrm{~b}$ \\
T8523 & $24.44 \mathrm{a}$ & T7546 & $23.01 \mathrm{~b}$ \\
T7543 & $24.21 \mathrm{a}$ & T6561 & $22.95 \mathrm{~b}$ \\
T6571 & $24.15 \mathrm{a}$ & T7062 & $22.90 \mathrm{~b}$ \\
T6591 & $24.04 \mathrm{a}$ & T8527 & $22.73 \mathrm{~b}$ \\
T6533 & $23.98 \mathrm{a}$ & T6577 & $22.44 \mathrm{c}$ \\
T7551 & $23.98 \mathrm{a}$ & T6594 & $22.44 \mathrm{c}$ \\
KM4 & $23.81 \mathrm{~b}$ & & \\
\hline
\end{tabular}

Keterangan: angka yang diikuti huruf yang sama pada kolom protein tidak berbeda nyata terhadap KM4 berdasarkan uji LSD pada taraf 5\%

Nilai koefisien korelasi yang menunjukkan keeratan hubungan antar karakter dapat dilihat pada Tabel 2. Pada analisis sidik lintas yang digunakan sebagai karakter tidak bebas adalah kandungan protein biji. Hasil analisis korelasi menunjukkan bahwa panjang polong berkorelasi negatif tidak nyata dan jumlah biji per polong berkorelasi negatif dan nyata dengan kandungan protein biji kacang tunggak. Dengan demikian dapat diartikan bahwa semakin panjang polong dan semakin banyak jumlah biji per polong maka kandungan protein biji akan semakin menurun karena protein yang ada pada satu polong dibagi sesuai dengan jumlah biji pada polong tersebut. Karakter panjang tangkai, panjang daun, umur berbunga dan umur panen berkorelasi positif tidak nyata terhadap kandungan protein biji kacang tunggak. Karakter tinggi tanaman dan jumlah cabang, berkorelasi positif dan sangat nyata terhadap protein. Hal ini menunjukkan bahwa semakin tinggi tanaman dan semakin banyak jumlah cabang maka kandungan protein biji semakin meningkat.

Tinggi tanaman berkorelasi positif dan sangat nyata terhadap panjang tangkai, juga berkorelasi positif dan nyata terhadap jumlah cabang dan panjang daun. Hal ini menunjukkan bahwa semakin tinggi tanaman maka jumlah cabang, ukuran panjang tangkai dan panjang daun meningkat. Tinggi tanaman berkorelasi negatif terhadap umur berbunga, umur panen, panjang polong dan jumlah biji per polong. Hal ini dapat diartikan bahwa semakin tinggi tanaman maka umur berbunga dan umur panennya semakin lama dengan panjang polong yang semakin pendek dan jumlah biji per polong semakin sedikit. Jumalh cabang berkorelasi positif terhadap 
panjang tangkai, panjang daun, umur berbunga dan panjang polong tetapi berkorelasi negatif terhadap umur panen dan jumlah biji per polong. Semakin banyak jumlah cabang maka akan terjadi penambahan ukuran panjang tangkai, panjang daun dan panjang polong tetapi juga dapat menyebabkan umur berbunga menjadi lebih lama, umur panen lebih cepat dan jumlah biji/[plpng menjadi lebih sedikit.
Panjang tangkai berkorelasi positif dan nyata terhadap panjang daun, ini menunjukkan bahwa semakin panjang tangkai maka akan terjadi peningkatan panjang daun. Panjang tangkai berkorelasi positif terhadap umur berbunga dan umur panen tetapi berkorelasi negatif dan sangat nyata terhadap panjang polong dan jumlah biji per polong. Hal ini berarti bahwa semakin panjang tangkai daun akan mengakibatkan berkurangnya panjang polong dan jumlah biji per polong.

Tabel 2. Nilai koefisien korelasi antar karakter genotipe mutan putatif kacang tunggak generasi M2

\begin{tabular}{lllllllll}
\hline Karakter & TT & JC & PT & PD & UB & UP & PP & JBP \\
\hline JC & $0.4^{*}$ & & & & & & & \\
PT & $0.64^{* *}$ & 0.15 & & & & & & \\
PD & $0.38^{*}$ & 0.16 & $0.38^{*}$ & & & & & \\
UB & -0.03 & 0.34 & 0.14 & -0.19 & & & & \\
UP & -0.17 & -0.11 & 0.09 & -0.24 & $0.58^{* *}$ & & & \\
PP & -0.07 & 0.15 & $-0.37^{*}$ & -0.22 & -0.19 & $-0.37^{* *}$ & & \\
JBP & -0.24 & -0.14 & $-0.38^{*}$ & 0.02 & -0.31 & $-0.41^{* *}$ & $0.66^{* *}$ & \\
Protein & $0.51^{* *}$ & $0.58^{* *}$ & 0.15 & 0.19 & 0.21 & 0.01 & -0.05 & $-0.49^{*}$ \\
\hline Keterang
\end{tabular}

Keterangan: $\mathrm{TT}=$ tinggi tanaman, $\mathrm{JC}=$ jumlah cabang, $\mathrm{PT}=$ panjang tangkai, $\mathrm{PD}=$ panjang daun, $\mathrm{UB}=$ umur berbunga, $\mathrm{UP}=$ umur panen, $\mathrm{PP}=$ panjang polong, JBP $=$ jumlah biji per polong, $* *=$ berkorelasi nyata pada taraf $1 \%,{ }^{*}=$ berkorelasi nyata pada taraf $5 \%$.

Panjang daun berkorelasi positif terhadap jumlah biji per polong tetapi berkorelasi negatif terhadap umur berbunga, umur panen dan panjang polong. Umur bunga berkorelasi positif dan sangat nyata terhadap umur panen tetapi berkorelasi negatif terhadap panjang polong dan jumlah biji per polong. Dengan demikian dapat dikatakan bahwa umur bunga dapat digunakan untuk menduga umur panen dimana semakin cepat umur berbunga maka umur panen juga semakin cepat dan sebaliknya. Karakter umur panen berkorelasi negatif sangat nyata terhadap panjang polong dan jumlah biji per polong. Sama halnya dengan umur berbunga, maka umur panen juga tidak dapat digunakan untuk menduga panjang polong dan jumlah biji per polong. Karakter panjang polong berkorelasi positif dan sangat nyata terhadap jumlah biji per polong, maka dapat diasumsikan bahwa semakin panjang polong maka jumlah biji.polong semakin banyak.

Karakter yang berkorelasi positif menunjukkan bahwa semakin tinggi nilai karakter tersebut maka karakter pada karakter tidak bebas akan mengalami peningkatan sehingga seleksi yang dilakukan adalah individu yang memiliki nilai karakter yang paling tinggi, karakter yang memiliki nilai koefisien korelasi negatif menunjukkan respon yang sebaliknya (Boer, 2011). Susilo et al. (2005) menyatakan bahwa karakter dengan nilai koefisien korelasi positif yang nyata dapat digunakan sebagai karakter seleksi. 
Nilai koefisien lintas yang menunjukkan pengaruh langsung dan tidak langsung melalui karakter lain terhadap kandungan protein biji terdapat pada Tabel 3. Hasil analisis sidik lintas berbagai karakter yang diamati pada kacang tunggak menghasilkan hubungan kausal antara karakter tersebut dengan kandungan protein biji sebagai karakter tidak bebas. Berdasarkan analisis sidik lintas ternyata tidak semua karakter memiliki pengaruh langsung yang besar. Tidak ada satu pun karakter yang memiliki nilai pengaruh langsung yang sama dengan pengaruh total yang ditunjukkan oleh nilai koefisien korelasi yang sama dengan nilai koefisien lintas.
Tabel 3 menunjukkan bahwa tinggi tanaman dan jumlah cabang memberikan pengaruh langsung yang cukup tinggi terhadap kandungan protein biji, akan tetapi pengaruh tidak langsung dari kedua karakter tersebut lebih tinggi. Panjang tangkai memberikan pengaruh langsung negatif tetapi memberikan pengaruh tidak langsung positif terhadap kandungan protein biji melalui karakter tinggi tanaman dan jumlah biji per polong yang cukup besar yaitu 0.29 dan 0.27. Pada karakter panjang daun memberikan pengaruh langsung cukup tinggi yaitu 0.24 tetapi pengaruh tidak langsungnya rendah dan karakter panjang polong memberikan pengaruh langsung positif cukup besar yaitu 0.31 tetapi pengaruh tidak langsungnya negatif.

Tabel 3. Pengaruh langsung dan tidak langsung karakter pertumbuhan dan produksi terhadap kandungan protein biji mutan putatif kacang tunggak generasi M2

\begin{tabular}{|c|c|c|c|c|c|c|c|c|c|c|c|}
\hline \multirow[t]{2}{*}{ Karakter } & \multirow{2}{*}{$\begin{array}{c}\text { Karakter } \\
\text { bebas } \\
\text { dibakukan }\end{array}$} & \multirow[t]{2}{*}{$\begin{array}{l}\text { Pengaruh } \\
\text { langsung }\end{array}$} & \multicolumn{8}{|c|}{ Pengaruh tidak langsung melalui karakter } & \multirow[t]{2}{*}{ Total } \\
\hline & & & $\mathrm{X} 1$ & $\mathrm{X} 2$ & $\mathrm{X} 3$ & $\mathrm{X} 4$ & $\mathrm{X} 5$ & $\mathrm{X} 6$ & $\mathrm{X} 7$ & $\mathrm{X} 8$ & \\
\hline TT & $\mathrm{X} 1$ & 0.45 & & 0.10 & -0.27 & 0.09 & 0.00 & 0.00 & -0.02 & 0.17 & 0.52 \\
\hline $\mathrm{JC}$ & $\mathrm{X} 2$ & 0.25 & 0.18 & & -0.06 & 0.04 & 0.03 & 0.00 & 0.05 & 0.10 & 0.59 \\
\hline PT & $\mathrm{X} 3$ & -0.43 & 0.29 & 0.04 & & 0.09 & 0.01 & 0.00 & -0.12 & 0.27 & 0.15 \\
\hline PD & $\mathrm{X} 4$ & 0.24 & 0.17 & 0.04 & -0.16 & & -0.02 & 0.00 & -0.07 & -0.01 & 0.19 \\
\hline UB & X5 & 0.10 & -0.01 & 0.08 & -0.06 & -0.05 & & -0.01 & -0.06 & 0.22 & 0.21 \\
\hline UP & X6 & -0.02 & -0.08 & -0.03 & -0.04 & -0.06 & 0.06 & & -0.12 & 0.29 & 0.02 \\
\hline PP & $\mathrm{X} 7$ & 0.31 & -0.03 & 0.04 & 0.16 & -0.05 & -0.02 & 0.01 & & -0.46 & -0.04 \\
\hline JBP & X8 & -0.70 & -0.11 & -0.03 & 0.16 & 0.00 & -0.03 & 0.01 & 0.21 & & -0.49 \\
\hline
\end{tabular}

Keterangan: $\mathrm{TT}=$ tinggi tanaman, $\mathrm{JC}=$ jumlah cabang, $\mathrm{PT}=$ panjang tangkai, $\mathrm{PD}=$ panjang daun, $\mathrm{UB}=$ umur berbunga, $\mathrm{UP}=$ umur panen, $\mathrm{PP}=$ panjang polong, $\mathrm{JBP}=$ jumlah biji per polong,

Analisis lintas menunjukkan bahwa karakter tinggi tanaman, jumlah cabang, panjang daun, umur berbunga dan panjang polong memberikan pengaruh langsung positif terhadap kandungan protein biji dengan nilai masing-masing $0.45, \quad 0.25, \quad 0.24, \quad 0.10$ dan 0.31 , sedangkan karakter panjang tangkai, umur panen dan jumlah biji per polong memberikan pengaruh langsung negatif terhadap kandungan protein biji dengan nilai cukup besar, kecil dan sangat besar yaitu $-0.43,-0.02$ dan -0.70 (Gambar 1). Dengan demikian dapat diartikan bahwa semakin tinggi ukuran tinggi tanaman, semakin banyak jumlah cabang, semakin bertambahnya ukuran panjang daun, semakin lama umur berbunga dan semakin bertambahnya ukuran panjang polong maka kandungan protein biji kacang tunggak akan semakin meningkat, tetapi semakin panjang 
ukuran tangkai daun, semakin lama umur panen dan semakin bertambahnya jumlah biji per polong maka dapat menurunkan kandungan protein pada biji kacang tunggak.

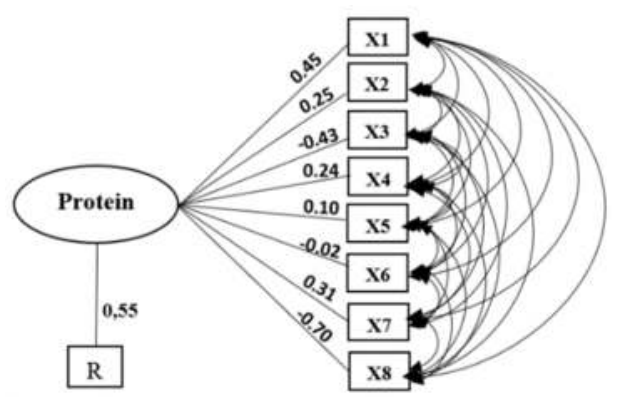

Gambar 1. Diagram lintas karakter agronomi terhadap kandungan protein biji genotipe mutan putatif kacang tunggak generasi M2

Nilai korelasi dapat digunakan untuk mengetahui respon berkorelasi dalam seleksi tidak langsung, artinya jika suatu karakter dan karakter lain memiliki respons berkorelasi maka perbaikan karakter yang sulit diamati dapat dilakukan dengan cara menyeleksi karakter lain yang mudah diamati (Bakhtiar et al. 2010). Kemajuan seleksi karakter yang sulit diamati dapat dihasilkan melalui respons berkorelasi dari karakter yang dijadikan sebagai kriteria seleksi, yang disebut sebagai seleksi tidak langsung yang dilakukan melalui karakter lain untuk satu karakter yang ingin diperbaiki (Falconer dan Mackay 1996).

Singh dan Chaudhary (1979) mengemukakan beberapa pedoman untuk menginterpretasikan hasil analisis sidik lintas. Jika nilai koefisien korelasi positif, tetapi pengaruh langsungnya negatif atau sangat kecil, maka pengaruhnya lebih banyak diakibatkan oleh pengaruh-pengaruh tak langsung yang lebih berperan. maka dapat dipertimbangkan untuk menggunakan karakter-karakter tak langsung tersebut dapat digunakan dalam seleksi simultan.
Sementara itu, jika koefisien korelasi bernilai negatif tetapi pengaruh langsungnya positif dan besar, dalam situasi ini dapat digunakan model seleksi simultan yang terbatas. Pembatasan dilakukan untuk menghilangkan pengaruh-pengaruh langsung yg tidak baik, dengan tujuan untuk memanfaatkan pengaruh langsungnya. Berdasarkan nilai korelasi dan analisis lintas dapat dinyatakan bahwa karakter tinggi tanaman dan jumlah cabang dapat digunakan sebagai karakter seleksi yang berpengaruh langsung terhadap kandungan protein biji.

Nilai residual effect sebesar 0.55 menunjukkan bahwa karakter tinggi tanaman, jumlah cabang, panjang daun, umur berbunga, umur panen, panjang polong dan jumlah biji per polong hanya mampu menjelaskan 0.45 pengaruhnya terhadap kandungan protein biji atau dapat dinyatakan bahwa sebesar 55\% kandungan protein biji kacang tunggak dipengaruhi oleh karakter lain yang tidak dapat dijelaskan pada hasil analisis sidik lintas yang dilakukan.

\section{SIMPULAN}

Keragaan mutan putatif kacang tunggak generasi M2 menunjukkan keragaman untuk sifat kandungan protein pada biji. Tinggi tanaman dan jumlah cabang dapat dijadikan karakter seleksi untuk menduga kandungan protein biji kacang tunggak.

\section{UCAPAN TERIMA KASIH}

Terima kasih kepada Pusat Kajian Hortikultura Tropika IPB atas Fasilitas dan Dana Hibah untuk "Pengembangan Sayur Indigenous" atas nama Sobir

\section{DAFTAR PUSTAKA}

[AOAC] Association of Official Analytical Chemist. 2001. Protein (crude) in animal feed, forage (plant tissue), grain, and oilseed. Journal AOAC International. 
[BKPPP] Badan Ketahanan Pangan dan Pelaksana Penyuluhan. 2014. Data Kandungan Gizi Bahan Pangan dan Olahan Golongan Kacang-kacangan dan Biji-bijian. Yogyakarta (ID): BKPPP Bantul.

Bakhtiar, Purwoko BS, Trikoesoemaningtyas, Dewi IS. 2010. Analisis korelasi dan koefisien lintas antarbeberapa sifat padi gogo pada media tanah masam. Journal Floratek, $5: 86-93$.

Boer D. 2011. Analisis variabilitas genetik dan koefisien lintas berbagai karakter agronomi dan fisiologi terhadap hasil biji dari keragaman genetik 54 asesi jagung asal Indonesia timur. Agroteknosos. 1(1): 35-43.

Falconer DS, Mackay TFC. 1996. Introduction to Quantitatve Genetics. Fourth Edition. London.

Okonya JS, Maass BL. 2014. Protein and iron composition of cowpea leaves: an evaluation of six cowpea varieties grown in Eastern Africa. African Jo. of Food Agriculture, Nutrition and Develop. 14: 9329-9340.

Singh RK, Chaudhary BD. 1979. Biometrical Methods in Quantitative Genetic Analysis. New Delhi (IN): Ludhiana Kalyani Pub.

Somaadmadja S. 1990. Sumber Daya Nabati Asia Tenggara I. Yogyakarta.

Susilo WA, Sulastri D, Djatiwaloejo. 2005. Seleksi dan pendugaan parameter genetik beberapa sifat batang bawah kakao (Theobroma cacao L.) pada semaian famili saudara tiri. Pelita Perkebunan 21(3): 147158.

Triyono A. 2010. Mempelajari pengaruh penambatan beberapa asam pada proses isolasi protein terhadap tepung protein isolat kcanag hijau (Phaseolus radiatus L.). Seminar Rekayasa Kimia dan Proses. 4-5 Agustus 2010 Universitas Diponegoro Semarang.

Wirnas D, Sobir, Surahman M. 2005. Pengembangan kriteria seleksi pada pisang ( musa sp.) berdasarkan analisis lintas. Buletin Agronomi 33(3): 48-54. 